\title{
A new species of Brachystelma (Apocynaceae: Asclepiadoideae) from Karnataka, India
}

\author{
Gundappa B.V. ${ }^{1}$, Sringeswara A.N. ${ }^{2 *}$, Vishwanath S. ${ }^{2}$ \& P. Venu ${ }^{3}$ \\ ${ }^{1}$ Wildlife Aware Nature Club, Nisarga Layout, Sri Shivakumara Swamy Circle, Tumakuru, Karnataka - 572 103, India \\ 2Mahatma Gandhi Botanical Garden, University of Agricultural Sciences, GKVK Campus, Bengaluru, Karnataka - 560 065, India \\ ${ }^{3}$ Environment Protection Training and Research Institute, Gachibowli, Hyderabad, Telanagana - 500 032, India \\ *E-mail: ansringesh@gmail.com
}

\begin{abstract}
A new species of Brachystelma R.Br., B. tumakurense (Apocynaceae: Asclepiadoideae Ceropegieae), is described and illustrated from Tumakuru district of Karnataka, India. It resembles $B$. bourneae Gamble, B. maculatum Hook.f. and B. rangacharii Gamble, but differs in corolla colour, corona structure and closing of the staminal corona over the gynostegium.
\end{abstract}

Keywords: Brachystelma tumakurense, Conservation, Synanthous species, Taxonomy.

\section{Introduction}

Brachystelma R.Br., the second largest genus in the tribe Ceropegieae with over 116 species is distributed in the Old-World tropics (Mabberley, 2017). They are slender stemmed with a brilliant display of colours in their flowers, especially in their corolla and coronal structures. Bruyns et al. (2017) argued for the merger of genus Brachystelma with Ceropegia L. based on molecular phylogenetic studies. Surveswaran et al. (2021) preferred to retain it as a separate entity from that of Ceropegia as both the genera exhibit distinctive floral morphologies. Pullaiah et al. (2019) have accounted for 33 species in Brachystelma in India, while a total of 38 taxa including six varieties were enumerated in a recent work (Prasad \& Venu, 2020). They are mainly distributed in Peninsular India in dry hill ranges. A few of them have been represented by their types

Received: 10.01.2021; Revised \& Accepted: 16.06.2021

Published Online: 30.06.2021 alone (Kambale et al., 2014; Venu \& Prasad, 2015; Prasad \& Venu, 2020). There are seven species from Karnataka, B. ciliatum Arekal \& T.M.Ramakrishna, B. edulis Collett \& Hemsl., B. elenaduense Sathyan., B. kolarensis Arekal \& T.M.Ramakrishna, B. maculatum Hook.f., B. shrirangii Kambale, Gholave \& Sardesai and B. volubile Hook.f. All of them exhibit erect stems and are non-climbing in nature.

During explorations in Devarayanadurga (Tumakuru district, Karnataka) material of Brachystelma was collected. It was found in flowering while bearing leaves (a synanthous species) and primarily comparable with $B$. bourneae Gamble, B. maculatum Hook.f. and B. rangacharii Gamble, but is distinctive in certain features and hence described here as a new species.

Brachystelma tumakurense Gundappa, Sringesw., Vishwan. \& Venu, sp. nov.

Figs. $1 \& 2$

Similar to B. bourneae, B. maculatum and $B$. rangacharii in having oblong or fusiform tuber, erect stem, linear leaves, condensed cymes with 3-6 flowers, but differs by greenish corolla lobes with maroon spots and maroon staminal corona which closes over the gynostegium $v s$. white corolla lobes with dark green spots and inflexed purple staminal corona in B. bourneae, lemon yellow corolla lobes with black spots and dark brown staminal corona adpressed to the back of the anthers in B. maculatum and pale white corolla lobes with white villous within and undulating staminal corona in $B$. rangacharii. 


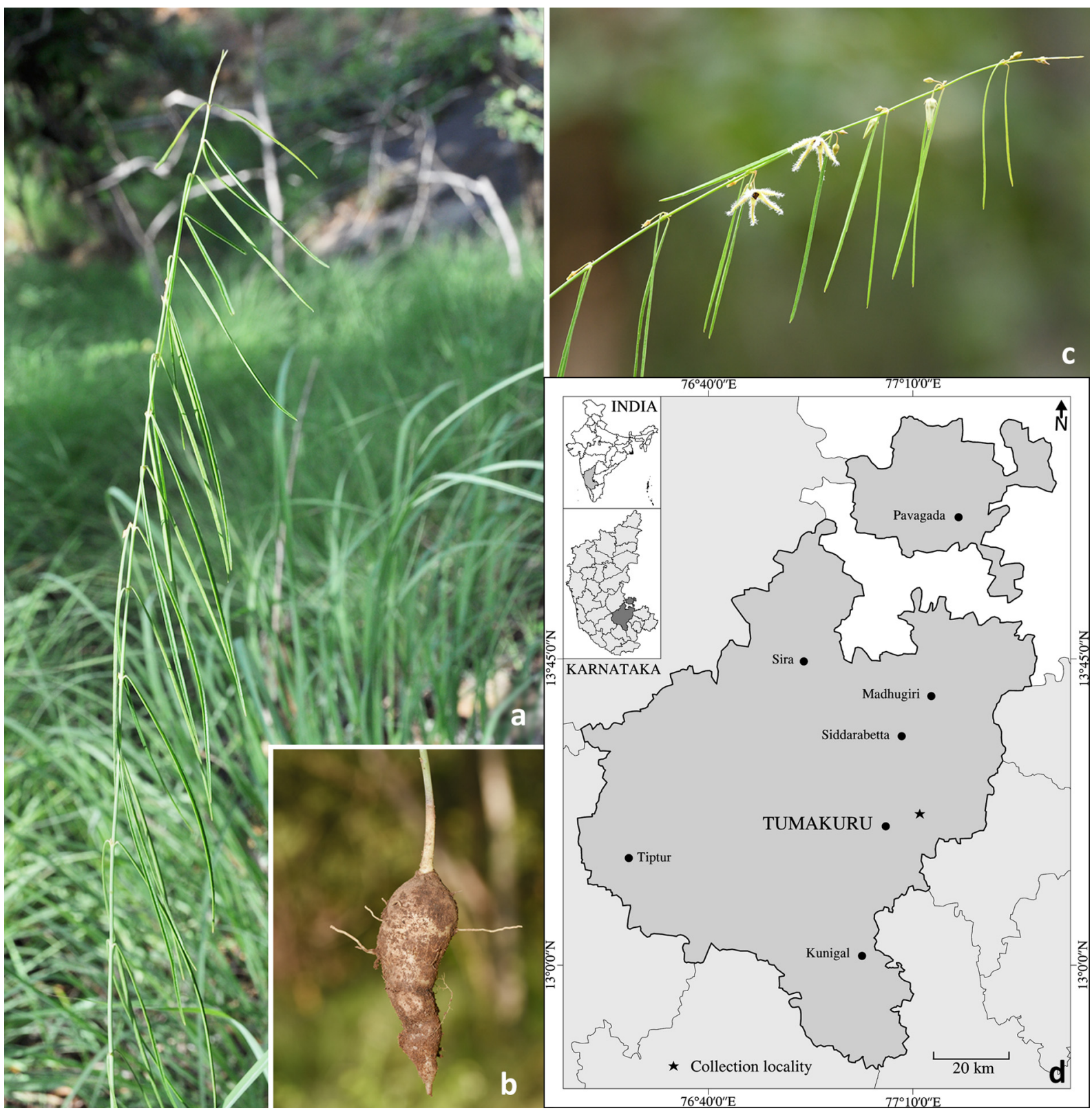

Fig. 1. Brachystelma tumakurense Gundappa, Sringesw., Vishwan. \& Venu sp. nov. a. Habit; b. Tuber; c. Part of flowering stem; d. Map showing collection locality (map from Survey of India; photos by A.N. Sringeswara).

Type: INDIA, Karnataka, Tumakuru district, Devarayanadurga, near Namada chilume, $700 \mathrm{~m}$, 30.07.2017, B.V. Gundappa \& V. Bhaskar 2546 (holo UASB!; iso BSI!).

Perennial tuberous herb, to $1 \mathrm{~m}$ high. Tuber oblong or fusiform, c. $7 \mathrm{~cm}$ long. Stem erect but weakly bent, usually un-branched, rarely branches from nodes below browsed ends, terete, faintly furrowed and ridged, glabrous/minutely puberulous; internodes 6-7 cm long. Leaves opposite, narrow, linear, 13-14 × 0.1-0.15 cm, unicostate, distantly setulose, glabrascent or minutely puberlous, recurved all along and appear cylindrical; petiole $c$. $3 \mathrm{~mm}$ long. Flowers 3-6, axillary, in umbellate cymes, campanulate, drooping, almost in each node from middle of the stem and upwards; peduncle 3-5 mm long, glabrous; bracts and bracteoles subulate, glabrous, 3-4 mm long. Mature flower buds 5-6 mm long, attenuate towards tip. Pedicels filiform, thread-like, 5-6 $\mathrm{mm}$ long, pale brown. 


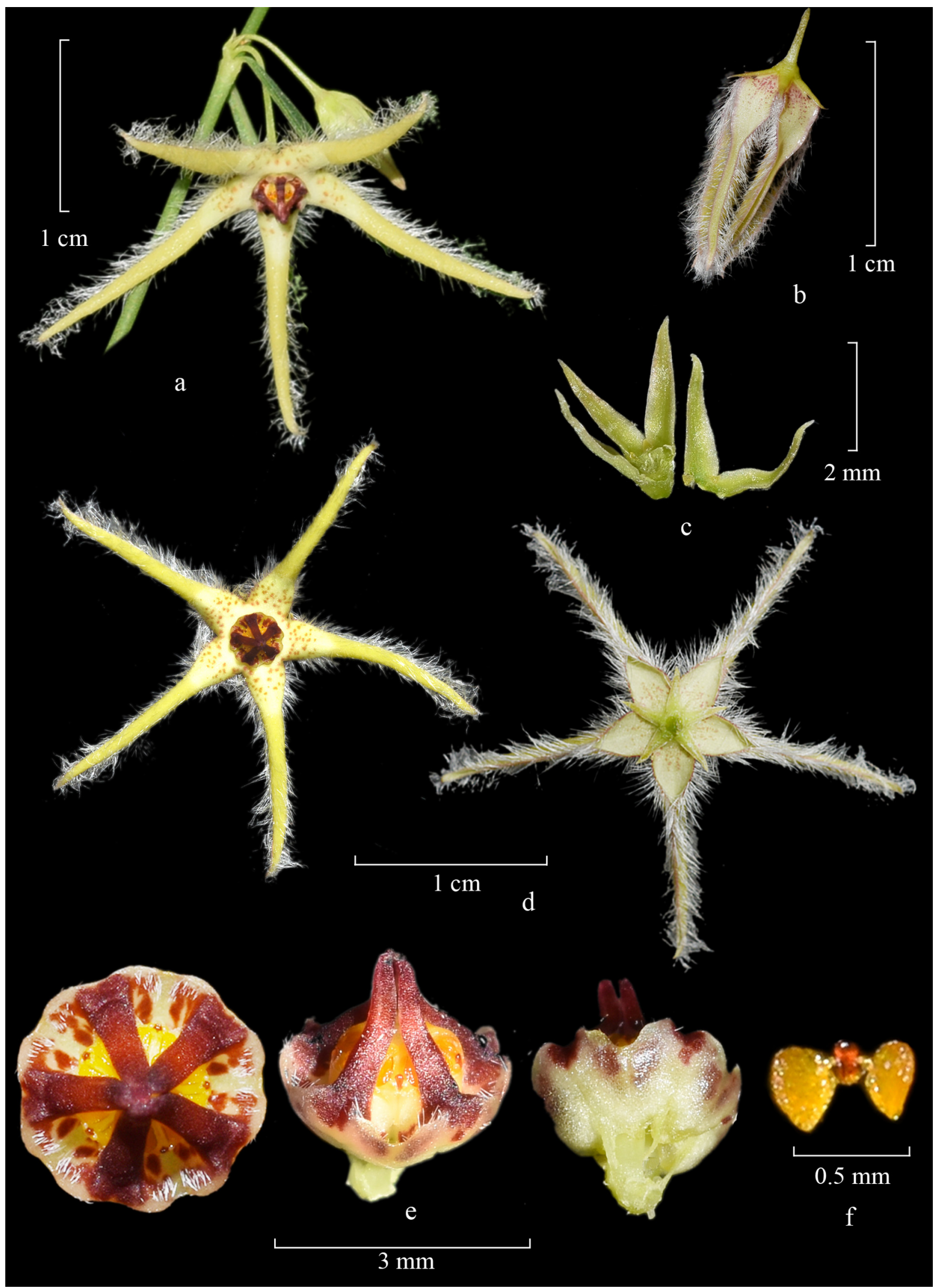

Fig. 2. Brachystelma tumakurense Gundappa, Sringesw., Vishwan. \& Venu. a. Inflorescence part of shoot; b. Mature bud; c. Calyx; d. Flower - upper and lower view; e. Corona in different views; f. Pollinarium (from B.V. Gundappa \& V. Bhaskar 2546; photos by A.N. Sringeswara). 
Calyx 5-lobed, lobes linear-lanceolate or subulate, 2.5-3 $\times 0.3 \mathrm{~mm}$, greenish below, maroon above. Corolla 9-11 mm long, 1.5-2 cm across (when open); corolla tube hardly visible, $<1 \mathrm{~mm}$ long, greenish with maroon spots outside; lobes broad at base, speckled with maroon spots, linear, 9-10 $\times 0.8-0.9 \mathrm{~mm}$, light green devoid of spots, densely white villous above all along the margins, free, excurved even at bud stage. Corona cupular; interstaminal corona lobes 5 , pale yellow with maroon patches, inner margins hairy, each lobe bilobed (10-lobuled); lobules orbicular, 0.45-0.5 mm long, obtuse; staminal corona lobes 5 , broadly linear, 1.35-1.5 × 0.45-0.5 mm, maroon, glabrous, joining loosely and conically at apex and above gynostegium. Gynostegium pentagonal, c. 1.37 $\mathrm{mm}$ across. Pollinaria ovoid, $0.5 \times 0.45 \mathrm{~mm}$, yellow, basally attached by shallow hyaline caudicles. Ovary c. $2 \mathrm{~mm}$ long; style short. Follicles paired, frequently one of them suppressed, cylindrical, c. $6 \mathrm{~cm}$ long, tapering towards the apex, divergent at maturity.

Flowering \& fruiting: Flowering from June to July and fruiting from August to September.

Habitat: About 16-18 individuals in one population were found growing amongst grasses, mainly Cymbopogon spp., in a southern moist mixed forest. The plants were distinctly visible since grasses had not attained their usual height owing to low rainfall in the year 2017. In fact, a few plants were found lacking the upper portions most likely due to browsing by wild animals. Usually, the browsed plants branch out from the node below and flower.

Distribution: Known only from the type locality, Devarayanadurga, Tumakuru district, Karnataka, India.

Etymology: The species is named after the Tumakuru district in Karnataka from where its type material was collected.

Specimen examined: INDIA, Karnataka, Tumukuru district, Devarayanadurga, near Namada chilume,
700 m, 02.07.2019, B.V. Gundappa, A.N. Sringeswara E Sahana BG 1432 (UASB).

Notes: The authors excluded species with erect habit that have patent flowers for comparison such as B. pullaiahii B.R.P.Rao, K.Prasad, Sadas., S.K.Basha, M.V.S.Babu \& Prasanna and B. penchalakonense Rasingam, Chorghe, Meve, Sankara Rao \& Prasanna since these differ in corona colour and lobation. The new species resembles in habit closest $B$. rangacharii, $B$. bourneae and B. maculatum, specifically in having erect stems, narrow linear leaves and axillary condensed cymes with 3-6 flowers and with fully patent and villous margined corolla lobes. However, these species differ in the colour of corolla and corona structure. Though some similarities exist between B. nallamalayanum K.Prasad \& B.R.P.Rao, and the new species in having terete, weak, erect stems often bent due to the weight of leaves and flowers, but differs from the former that has pinkish hairy corolla lobes and a black corona with triangular lobules. Principally, none of these species are identical to the new material described here in staminal corona, which closes in over the gynostegium and quite above.

\section{Acknowledgements}

The authors are indebted to Dr. M. Sanjappa, former Director, Botanical Survey of India, Kolkata for valuable suggestions and the authorities of University of Agricultural Sciences, GKVK campus, Bengaluru for facilities. The author VS acknowledges the National Post Doctoral Fellowship received under SERB, DST (PDF/2017/ 002230).

\section{Literature Cited}

BRUYNS P.V., KLAK C. \& P. HANÁÈEK 2017. A revised, phylogenetically based concept of Ceropegia (Apocynaceae). South African Journal of Botany 112:399436. https://doi.org/10.1016/j.sajb.2017.06.021

KAMBALE S.S., SURVESWARAN S. \& S.R. YADAV 2014. Two new species of Brachystelma Sims 
(Apocynaceae-Asclepiadoideae-Ceropegieae) from the Western Ghats of India. Kew Bulletin 69: 1-10. https:// doi.org/10.1007/s12225-014-9493-1

MABBERLEY D.J. 2017. Mabberley's Plant-Book: a portable dictionary of plants, their classification and uses, Fourth Edition. Cambridge University Press, Cambridge.

PRASAD K. \& P. VENU 2020. A taxonomic revision of the genus Brachystelma R.Br. in India. Bishen Singh Mahendra Pal Singh, Dehra Dun.

PULLAIAH T., KARUPPUSWAMY S. \& K.S.R.
MURTHY 2019. Monograph on Brachystelma and Ceropegia in India. CRC Press, Boca Raton.

SURVESWARAN S., KAMBALE S.S., SRIVASTAV M., PUNEKAR S.A., YADAV S.R. \& K.P. KARANTH 2021. Origin and diversification of Indian Ceropegieae (Apocynaceae) and its possible relation to the Indian monsoon. Journal of Systematics and Evolution 59 (1): 93-112. https://doi.org/10.1111/jse.12578

VENU P. \& K. PRASAD 2015. The existential crisis in Indian Brachystelma (Apocynaceae). Current Science 109: 680-682. 